\title{
Correlation between pathological data and the RNA expression of p53 or p53-targeted genes in primary invasive ductal breast carcinomas: A preliminary study
}

\author{
LOREDANA ALBONICI ${ }^{1}$, ROBERTO P. SORGE ${ }^{2}$, GIUSEPPE SANTEUSANIO ${ }^{3}$, \\ PAOLO GAROFANO $^{1}$, VITTORIO MANZARI $^{1}$ and GIOVANNI BARILLARI ${ }^{1}$ \\ Departments of ${ }^{1}$ Experimental Medicine, ${ }^{2}$ Neurosciences, and ${ }^{3}$ Biopathology, \\ University 'Tor Vergata', Via Montpellier 1, 00133 Rome, Italy
}

Received September 23, 2009; Accepted November 9, 2009

DOI: $10.3892 /$ or_00000740

\begin{abstract}
The protein expression of the growth suppressive p53 transcription factor and its inhibitor human double minute $2(\mathrm{Hdm} 2)$ is altered in ductal breast carcinomas (DBC). However, the assessment of $\mathrm{p} 53$ and/or $\mathrm{Hdm} 2$ protein levels in DBC tissues was found to have a questionable prognostic significance. We evaluated the RNA expression of $\mathrm{p} 53$, hdm 2 , and the p53-targeted p21 waf-1 and thrombospondin (tsp)-1 by primary DBC tissues, then correlated the RNA levels with patient clinicopathological data. The mean RNA expression level of p53 and that of hdm2 were elevated in large-sized, poorly differentiated, node-positive DBC, while a high p $21^{\text {waf- }}$ or tsp- 1 mean expression level comprised small-sized, low-grade, node-negative tumors. Further analyses found that the correlation between the RNA expression of p53 and that of its targeted genes was reduced as tumor aggressiveness increased. However, for all the examined genes, association of the intensity of RNA expression with the pathological data was not statistically significant $(p>0.05)$. Altogether, our preliminary RNA data confirm the results from previous protein studies, indicating that despite $\mathrm{p} 53$ expression and activity show a trend to vary in association with DBC clinical features, neither p53 nor its transcriptional targets can accurately monitor the behaviour of invasive DBC.
\end{abstract}

\section{Introduction}

The $\mathrm{p} 53$ protein is a trancription factor inducing the expression of genes regulating cell growth or death (reviewed in ref. 1).

Correspondence to: Dr Giovanni Barillari, Department of Experimental Medicine, University 'Tor Vergata', Via Montpellier 1, 00133 Rome, Italy

E-mail: barillar@uniroma2.it

Key words: p53, Hdm2, p21 ${ }^{\mathrm{WAF} 1}$, TSP-1, breast carcinoma
Upon cellular stress p53 is activated to promote cell cycle arrest (providing time for stressed cells to recover) or cellular apoptosis (1). By preventing the survival and proliferation of aberrant cells, p53 avoids tumor onset (1). Moreover, by inducing TSP-1, a potent inhibitor of new blood vessel formation, p53 also counteracts the growth of established tumors (1).

The importance that p53 has in anti-tumor surveillance is sustained by the finding that most human cancers display functionally inactive p53, due to p53 mutations or to the upregulation of $\mathrm{Hdm} 2$, a $\mathrm{p} 53$-induced protein which feedback terminates p53 trans-activating function (reviewed in ref. 2).

Among the tumors in which p53 inactivation and $\mathrm{Hdm} 2$ deregulation are particularly evident is DBC, one of the most common and severe cancer affecting women (reviewed in ref. 3).

It has been shown that concomitantly with DBC growth and invasion of the basement membrane, $\mathrm{Hdm} 2$ protein levels increase, while p53-induced proteins including the p21 ${ }^{\text {waf-1 }}$ cell cycle inhibitor and TSP-1 are reduced (4-8).

The findings reported above suggested earlier that measuring the expression of p53 or its transcriptional targets could monitor human DBC progression, having a prognostic relevance. However, studies evaluating this possibility gave contrasting results (4-13). This could depend on the fact that DBC expression of p53 or its targeted molecules was assayed mostly at the protein level. In this regard, it has to be considered that in many types of tumors, breast cancer included, p53, Hdm2, p21 $1^{\text {waf- } 1}$, or TSP-1 undergo post-transcriptional and/or post-translational modification variably and unpredictably augmenting their levels $(1,2,14-16)$.

Noteworthy, as compared to the large body of information existing on p53 protein expression, little is known on p53 RNA levels in breast cancers (17). In addition, with regard to primary human DBC, p53-trancribed genes were generally analysed one at a time in separate studies, independently of p53 RNA expression (18-20).

The present study assayed the RNA expression of p53 and the p53-trancribed hdm2, p21 $1^{\text {waf- } 1}$, and tsp- 1 by human primary DBC. The intensity of the RNA expression of the above-mentioned genes was then correlated to the patients' clinical status. 


\section{Materials and methods}

Study group. Tissue samples from 31 patients with invasive, pure DBC were provided by the Sant' Eugenio Hospital of Rome. Informed consent was obtained from the patients. Tumors were divided into two groups: A) DBC having size (T) $<1 \mathrm{~cm}$, low histological grade (G1), and no lymph node invasion $\left(\mathrm{N}^{-}\right)$; B) DBC presenting $\mathrm{T}>1 \mathrm{~cm}$, high histological grade $(\mathrm{G} 2-3)$, and lymph node invasion $\left(\mathrm{N}^{+}\right)$. All examined patients were metastasis-free (M0). Biopsies were dissected by a pathologist during local excision or mastectomy. Tissue areas presenting necrosis or non-matching to DBC diagnostic were excluded prior to RNA extraction. Specimens were kept frozen until they were processed for RNA extraction.

$R N A$ extraction and reverse transcriptase-polymerase chain reaction $(R T-P C R)$ analysis. Frozen DBC tissue samples were homogenised in TRIzol (1 $\mathrm{ml} / \mathrm{g}$ of tissue), and total RNA was extracted according to manufacturer's instructions (Invitrogen, Milan, Italy). Only RNA samples with an absorbance A260/280 ratio $>1.8$ and no visible degradation by $1 \%$ agarose gel electrophoresis and ethidium bromide staining were used for RT-PCR. Because of partial RNA degradation, seven samples (three from group A and four from group B tumors) were excluded from the study. One $\mu \mathrm{g}$ of total RNA from each of the remaining 24 DBC samples was reversetranscribed using $200 \mathrm{U}$ of Superscript III, $10 \mathrm{mM}$ DTT, 20 $\mathrm{U}$ of RNAse inhibitor, $2.5 \mu \mathrm{M}$ of random hexamers, $1 \mathrm{mM}$ of each dNTP (all from Invitrogen) in a final volume of $20 \mu \mathrm{l}$. Reactions were performed at $42^{\circ} \mathrm{C}$ for $60 \mathrm{~min}$. The cDNA product $(2 \mu 1)$ was amplified with $2.5 \mathrm{U}$ of Taq DNA polymerase (Invitrogen) in a final volume of $50 \mu 1$ containing $200 \mu \mathrm{M}$ of each $\mathrm{dNTP}$ and $50 \mathrm{pmol}$ of each primer derived from the $\mathrm{p} 53$, p $21^{\text {waf- }}$, tsp-1, or hdm-2 cDNA sequence. In order to avoid amplification of contaminant DNA, all of primers were designed overlapping between different exons. Primers for p53 were: forward, 5'-AAGTCTGTGACTTGC ACGTACTCC-3', reverse 5'-GTTGTTGGGCAGTGCTCG CTTAGT-3' (Gene Bank accession no. AF 307851, PCR product base pairs 576). Primers for $\mathrm{p} 21^{\text {waf- } 1}$ were: forward, 5'-TAGTTCTACCTCAGGCAGCTCAAG-3', reverse 5'-AC AGTCCAGGCCAGTATGTTACAG-3' (Gene Bank accession no. U03106, PCR product base pairs 433). Primers for tsp-1 were: forward, 5'-GATGGAGAATGCTGAGT TGGACGT-3', reverse 5'-TCACATCGGTTGTTGAGGC TATCG-3' (Gene Bank accession no. NM_003246, PCR product base pairs 723). Primers for hdm2 were: forward, 5'-GTAGAATTTGAAGTTGAATCT-3', reverse 5'-CTAGG GGAAATAAGTTAGCAC-3' (Gene Bank accession no. NM_002392, PCR product base pairs 738). The RT reaction was normalised by amplifying samples for glyceraldehyde3-phosphate dehydrogenase (gapdh) as housekeeping gene. Primers for gapdh were: forward 5'-TGTTCGTCATGGGT GTGAAACATG-3', reverse 5'-CTGCTTCACCACCTTCT TGATGTC-3' (Gene Bank accession no. M33197, PCR product base pairs 404). All primers were purchased from Invitrogen. Amplification consisted of $30 \mathrm{sec}$ at $94^{\circ} \mathrm{C}, 30 \mathrm{sec}$ at $65^{\circ} \mathrm{C}$ and $30 \mathrm{sec}$ at $72^{\circ} \mathrm{C}$ for 35 cycles, preceded by a first step of $2 \mathrm{~min}$ at $94^{\circ} \mathrm{C}$ and followed by a final extension at $72^{\circ} \mathrm{C}$ for $7 \mathrm{~min}$. The identity of the amplicons was confirmed
Table I. The p53 gene and its targeted genes hdm2, p21 waf-1 or tsp-1 are expressed in human primary DBC tissues.

\begin{tabular}{|c|c|c|c|c|}
\hline \multirow[b]{2}{*}{ Gene } & \multicolumn{2}{|c|}{$\begin{array}{l}\text { Relative expression } \\
\text { in group A }\end{array}$} & \multicolumn{2}{|c|}{$\begin{array}{c}\text { Relative expression } \\
\text { in group B }\end{array}$} \\
\hline & $\begin{array}{c}\text { Mean } \\
\text { expression }\end{array}$ & Range & $\begin{array}{c}\text { Mean } \\
\text { expression }\end{array}$ & Range \\
\hline p53 & 0.62 & $(0.02-2.36)$ & 0.94 & $(0.15-2.06)$ \\
\hline$H d m 2$ & 0.44 & $(0.1-1.23)$ & 0.64 & $(0.09-1.54)$ \\
\hline$p 21^{\text {waf-1 }}$ & 1.0 & $(0.4-3.35)$ & 0.81 & $(0.15-3.23)$ \\
\hline tsp-1 & 0.98 & $(0.01-2.24)$ & 0.76 & $(0.0-2.93)$ \\
\hline
\end{tabular}

Total RNA was extracted from small-sized, low grade, node-negative (group A) or large-sized, high grade, node-positive (group B) primary invasive DBC. The RNA expression of $\mathrm{p} 53$, hdm2, p21 $1^{\text {waf- } 1}$ or tsp-1 was assayed by RT-PCR. The gadph housekeeping gene was employed to normalize the values. Shown are the average results and the range (minimal and maximal values) of the intensity of $\mathrm{p} 53, \mathrm{hdm} 2, \mathrm{p} 21^{\text {waf-1 }}$ or tsp-1 RNA expression. Values refer to the densitometric units after normalization to gapdh RNA expression.

by sequencing. The PCR products were electrophoresed through a $1.8 \%$ agarose gel and stained with ethidium bromide. Bands were photographed using Polaroid film and ultraviolet trans-illuminator. The intensity of p53-, p21 waf-1 tsp-1-, hdm2-, or gapdh-related bands was quantified by employing the Molecular Imager VersaDoc MP 4000 (BioRad, Hercules, CA), and analysed with the Quantity One software (Bio-Rad).

Statistical analysis. All data analysis was performed using the Statistical Package for the Social Sciences Windows, version 13.0 (SPSS, Chicago, IL, USA). It was estimated that 12 patients for groups were sufficient to achieve an $89 \%$ power ( $\alpha$ level of 0.05 ) in detecting a variation of mean p53 (considered as the 'golden parameter') over the 95\% of confidance interval (Software: PASS per power analysis, NCSS Statistical Software, Kaysville, UT-www.ncss.com).

Descriptive statistics consisted of the mean \pm standard deviation for gaussian distributions (after confirmation with Kolmogorov-Smirnov test) and homogeneity of variances (after Levene's test). The ANOVA (one-way) test was performed for comparison between groups. Correlation of variables was performed with the $r$ of Pearson coefficient. A p-value of $<0.05$ was considered statistically significant.

\section{Results}

The p53, hdm2, p21 waf-1 and tsp-1 RNA levels were analysed by RT-PCR in tissues from 24 primary, invasive DBC, and then normalised to the gapdh housekeeping gene. Results indicated that all DBC expressed detectable levels of p53 as well as its targeted genes (Table I).

The intensity of p53, hdm2, p2 $1^{\text {waf- } 1}$ or tsp- 1 RNA expression measured in the 12 group $\mathrm{B}\left(\mathrm{T}>1 \mathrm{~cm}, \mathrm{G} 2-3, \mathrm{~N}^{+}\right)$ 

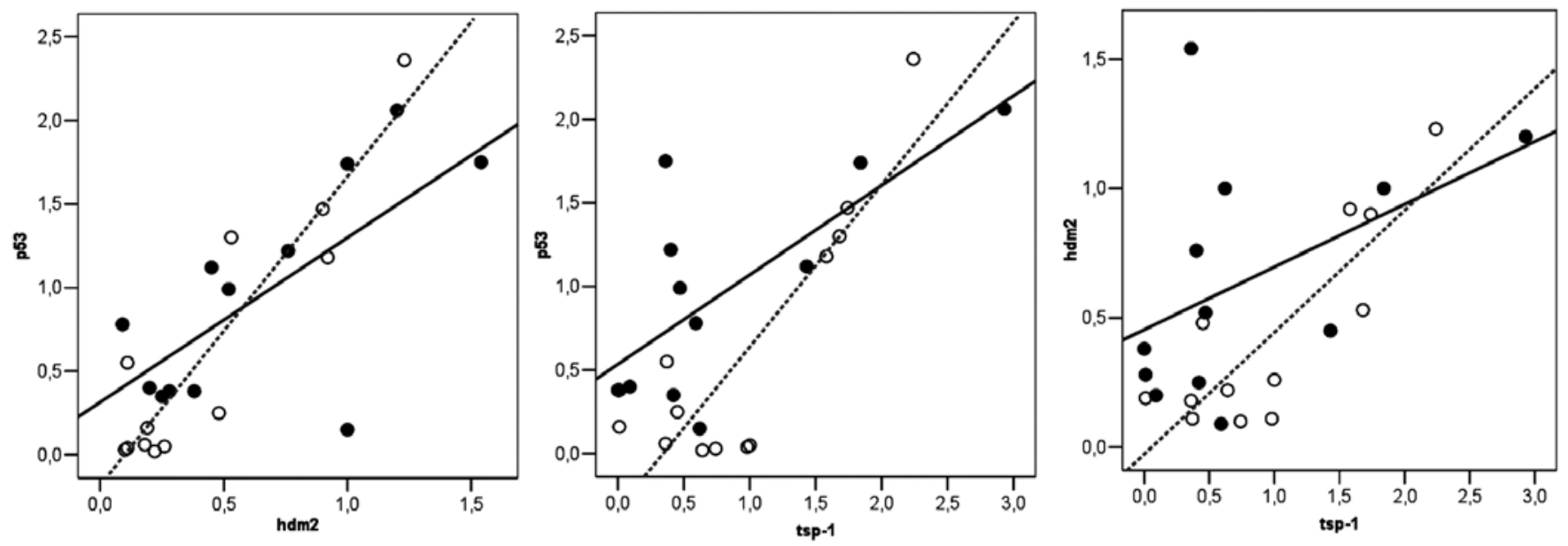

OA .... fit line for $A$

Figure 1. Correlation between the RNA expression levels of p53, hdm2 and/or tsp-1 within group A or B primary DBC. Correlation between gene expression data were calculated using Pearson correlation test. The $\mathrm{r}$ of Pearson coefficient defining relationship between p53 and hdm2 RNA expression (left panel) was 0.92 in small-sized, low grade, node-negative (group A) primary DBC, and 0.70 in large-sized, high grade, node-positive (group B) primary DBC. Concerning the correlation between p53 and tsp-1 RNA expression (central panel), the $\mathrm{r}$ coefficient was 0.86 in group A tumors, and 0.73 in group B tumors. The $\mathrm{r}$ of Pearson coefficient defining relationship between hdm 2 and tsp-1 RNA expression (right panel) was 0.84 in group A, and 0.47 in group B.

tumor biopsies was compared to the relative RNA expression by the 12 group $A\left(\mathrm{~T}<1 \mathrm{~cm}, \mathrm{G} 1, \mathrm{~N}^{-}\right)$tumor samples.

As shown in Table I, the mean of p53 and hdm2 RNA expression levels detected in large-sized, high grade, nodepositive (group B) samples was higher $(+52 \%$ for $\mathrm{p} 53$, and $+45 \%$ for hdm 2 ) than that measured in small-sized, low grade, node-negative (group A) DBC.

The opposite trend was verified for $\mathrm{p} 21^{\text {waf- } 1}$ and tsp- 1 RNA levels. Specifically, as compared to group A cancers, the mean of p $21^{\text {waf- }}$ and tsp-1 RNA levels decreased by 19 and $-22 \%$, respectively, in group B tumors (Table I).

Association of p53, hdm2, p21waf-1, and tsp-1 RNA expression levels with patients' clinicopathological data was statistically verified by ANOVA (one-way) test. Statistically significant associations were not observed between the clinical data analysed and the relative expression of $\mathrm{p} 53$ $(\mathrm{p}=0.281), \operatorname{hdm} 2(\mathrm{p}=0.250), \mathrm{p} 21^{\text {waf- }}(\mathrm{p}=0.571)$, or tsp-1 $(\mathrm{p}=0.502)$.

The $r$ of Pearson coefficient was then calculated in order to determine, within DBC belonging to the same group, the correlation between p53 gene expression and that of the examined p53-targeted genes.

Results demonstrated a positive and significant correlation between the relative expression levels of p53 and hdm2. This was more evident in group A $(r=0.92)$ than in group B ( $r=0.70)$ tumors (Fig. 1, left panel).

Also p53 and tsp-1 RNA expression were significantly correlated in the groups. Once again, this was more appreciable in group A $(r=0.86)$ than in group $\mathrm{B}(\mathrm{r}=0.73)$ tumors (Fig. 1, central panel).

At variance with hdm 2 or tsp-1, however, p53 RNA expression was not correlated with that of $\mathrm{p} 21^{\text {waf- } 1}$ in DBC in either group $\mathrm{A}(\mathrm{r}=0.06)$ or $\mathrm{B}(\mathrm{r}=0.17)$.

Finally, in group A tumors the RNA expression of hdm2 was significantly correlated with that of tsp-1 ( $\mathrm{r}=0.84)$, while in group B this correlation was strongly reduced $(r=0.47)$ (Fig. 1, right panel).

\section{Discussion}

Here, we evaluated p53, hdm2, p2 $1^{\text {waf-1 }}$, and tsp-1 gene expression by primary invasive DBC. Statistical analysis estimated that 12 patients with small-sized, low grade, nodenegative tumors, and the same number of individuals displaying large-sized, high grade, node-positive cancers, were representative of the general population of DBC patients.

Results from RT-PCR analysis indicate that the mean of p53 RNA expression levels is higher in large-sized, scarcely differentiated, node-positive DBC than in less aggressive tumors. This confirms results from immunohistochemical studies $(7,10,12)$, and it suggests a molecular mechanism for the high p53 protein levels present in human $\mathrm{DBC}$, in addition to the frequently occurring impairment of p53 degradation. A possible role for the up-regulation of p53 RNA expression in tumorigenesis is sustained by the finding that high p53 RNA levels are detected in various types of human cancers $(21,22)$.

As for $\mathrm{p} 53$, the mean intensity of hdm2 gene expression shows a trend to be associated with tumor aggressiveness. Again, this results is in agreement with the fact that increasing Hdm2 protein levels significantly associate with augmented DBC size and tumor cell proliferation (7), consistent with Hdm2 capability of abrogating p53 growth suppressive properties (2). In this regard, it has to be highlighted that up-regulation of hdm2 gene expression occurs in many, different human tumors, leading to the synthesis of $\mathrm{Hdm} 2$ protein at amounts that are sufficient to inactivate p53 (2).

Differently from p53 and hdm 2 , the mean of p $21^{\text {waf- } 1}$ RNA expression levels is high in small-sized, low grade, node- 
negative (group A) DBC, as compared to group B tumors. This result confirms the fact that in invasive DBC, p21 waf-1 protein expression directly relates to low histological grade, and inversely associates with tumor growth $(4,8,10,11)$. Moreover, in DBC belonging to the A group also the mean of tsp-1 RNA levels is high. This is in accordance with the finding that breast carcinoma cells express TSP-1 protein in a manner inversely related to tumor size (5).

However, when we associated the values of RNA expression intensity measured in DBC tissues to the patients' clinicopathological data no statistically significant relationship was found for any of the examined genes.

In this context, it has to be considered that p53, Hdm2, p $21^{\text {waf- } 1}$ or TSP-1 protein levels were found to associate with the size or grade of invasive breast carcinomas, despite correlating with prognosis $(5,8,9,11,12)$.

Still, the fact that the p53-targeted hdm2, p21 waf- 1 or tsp-1 genes are expressed by all the examined tissues suggests that in those DBC the p53 protein is transcriptionally active and operating.

When the relationship between the RNA levels of p53 and its transcriptional targets within the two DBC groups was evaluated, the expression of p53 and that of the p53-targeted hdm 2 and tsp-1 genes appeared to be more correlated in small-size, low grade, node-negative tumors than in aggressive/advanced DBC. This suggests that DBC clinical worsening parallels p53 functional impairment, in spite of concurrent p53 RNA over-expression.

The fact that hdm2 RNA levels significantly relate to those of the p53-transcribed tsp-1 gene in group A but not B tumors, supports the hypothesis that the increase in hdm2 RNA levels observed in group B is such to impair p53 activity.

Differently from the other p53-targeted genes, correlation between the RNA expression levels of p53 and p21 waf-1 is not significant. In this regard, it has to be considered that breast carcinoma cells, as well as other cancer cell types, can express p21 waf-1 independently of p53 (23-26).

In conclusion, the results we obtained at the RNA level are consistent with previous studies performed at the protein level, which indicated that p53 or its transcriptional targets should not be considered as molecular markers capable of predicting the behaviour of invasive DBC.

Definitely, however, our study requires confirmation in a larger series of patients. In addition, given that here we analyzed only invasive DBC, future studies should evaluate the RNA expression of p53 and its targeted genes in DBC in situ, and in hyperplastic breast lesions, as suggested by a recent study on pre-malignant skin lesions (27).

\section{Acknowledgements}

This study was supported by a grant from the Italian Ministry of Health (Ricerca Finalizzata Oncologia) to G.B.

\section{References}

1. Vousden KH and Prives C: Blinded by the light: the growing complexity of p53. Cell 137: 413-431,2009.

2. Klein C and Vassilev LT: Targeting the p53-MDM2 interaction to treat cancer. Br J Cancer 91: 1415-1419, 2004.
3. Wiechmann L and Kuerer HM: The molecular journey from ductal carcinoma in situ to invasive breast cancer. Cancer 112: 2130-2142, 2008.

4. Domagala W, Welcker M, Chosia M, Karbowniczeck M, Harezga B, Bartkova J, Bartek J and Osborn M: p21WAF1/cip1 expression in invasive ductal breast carcinoma: relationship to p53, proliferation rate, and survival at 5 years. Virchows Arch 439: 132-140, 2001.

5. Gasparini G, Toi M, Biganzoli E, Dittadi R, Fanelli M, Morabito A, Boracchi P and Gion M: Thrombospondin-1 and -2 in node-negative breast cancer: correlation with angiogenic factors, p53, cathepsin D, hormone receptors and prognosis. Oncology 60: 72-80, 2001.

6. Jin L, Yuan RQ, Fuchs A, Yao Y, Joseph A, Schwall R, Schnitt SJ, Guida A, Hastings HM, Andres J, Turkel G, Polverini PJ, Goldberg ID and Rosen EM: Expression of interleukin-1 beta in human breast carcinoma. Cancer 80: 421-434, 1997.

7. Vestey SB, Sen C, Calder CJ, Perks CM, Pignatelli M and Winters ZE: p14 arf expression in invasive breast cancers and ductal carcinoma in situ - relationships to p53 and Hdm2. Breast Cancer Res 6: 571-585, 2004.

8. Pinto AE, André S, Laranjeira C and Soares J: Correlations of cell cycle regulators (p53, p21, pRb and mdm2) and c-erbB-2 with biological marker of proliferation and overall survival in breast cancer. Pathology 37: 45-50, 2005.

9. Bankfalvi A, Tory K, Kemper M, Breukelmann D, Cubik C, Poremba C, Fuzesi L, Lellè RJ and Bocker W: Clinical relevance of immunohistochemical expression of p53-targeted gene products $\mathrm{mdm}-2, \mathrm{p} 21$ and bcl-2 in breast carcinoma. Pathol Res Pract 196: 489-501, 2000.

10. Ceccarelli C, Santini D, Chieco P, Lanciotti C, Taffurelli M, Paladini G and Marrano D: Quantitative p21(waf-1)/p53 immunohistochemical analysis defines groups of primary invasive breast carcinomas with different prognostic indicators. Int J Cancer 95: 128-134, 2001.

11. Gohring UJ, Bersch A, Becker M, Neuhaus W and Schondorf T: p21(waf) correlates with DNA replication but not with prognosis in invasive breast cancer. J Clin Pathol 54: 866-870, 2001.

12. Kourea HP, Koutras AK, Zolota V, Grimani I, Tzoracoeleftherakis E, Koukoras D, Fountzilas G, Gogas H, Kyriakou K, Adamou A and Kalofonos HP: Expression of p27KIP1, p21WAF1 and p53 does not correlate with prognosis in node-negative invasive ductal carcinoma of the breast. Anticancer Res 26: 1657-1668, 2006.

13. Michels JJ, Duigou F, Marnay J, Henry-Amar M, Delozier T, Denoux Y and Chasle J: Flow cytometry and quantitative immunohistochemical study of cell cycle regulation proteins in invasive breast carcinoma: prognostic significance. Cancer 97: 1376-1386, 2003.

14. Okamoto M, Ono M, Uchiumi T, Ueno H, Kohno K, Sugimachi K and Kuwano M: Up-regulation of thrombospondin-1 gene by epidermal growth factor and transforming growth factor beta in human cancer cells: transcriptional activation and messenger RNA stabilization. Biochim Biophys Acta 1547: 24-34, 2002.

15. Giles KM, Daly JM, Beveridge DJ, Thomson AM, Voon DC, Furneaux HM, Jazayeri JA and Leedman PJ: The 3'-untranslated region of $\mathrm{p} 21 \mathrm{WAF} 1 \mathrm{mRNA}$ is a composite cis-acting sequence bound by RNA-binding proteins from breast cancer cells, including $\mathrm{HuR}$ and poly(C)-binding protein. J Biol Chem 278: 2937-2946, 2003.

16. Bode AM and Dong Z: Post-translational modification of p53 in tumorigenesis. Nat Rev Cancer 4: 793-805, 2004.

17. Shin BK, Lee Y, Lee JB, Kim HK, Lee JB, Cho SJ and Kim A: Breast carcinomas expressing basal markers have poor clinical outcome regardless of estrogen receptor status. Oncol Rep 19: 617-625, 2008.

18. Brown LF, Guidi AJ, Schnitt SJ, Van De Water L, IruelaArispe ML, Yeo TK, Tognazzi K and Dvorak HF: Vascular stroma formation in carcinoma in situ, invasive carcinoma, and metastatic carcinoma of the breast. Clin Cancer Res 5: 1041-1056, 1999.

19. Bueso-Ramos CE, Manshouri T, Haidar MA, Yang Y, McCown P, Ordonez N, Glassman A, Sneige N and Albitar M: Abnormal expression of MDM-2 in breast carcinomas. Breast Cancer Res Treat 37: 179-188, 1996.

20. Trimis G, Chatzistamou I, Politi K, Kiaris H and Papavassiliou AG: Expression of p21waf1/cip1 in stromal fibroblasts of primary breast tumors. Hum Mol Genet 17: 3596-3600, 2008. 
21. Yokoyama M, Yamanaka Y, Friess H, Buchler M and Korc M: p53 expression in human pancreatic cancer correlates with enhanced biological aggressiveness. Anticancer Res 14: 2477-2483, 1994.

22. Kanellou P, Zaravinos A, Zioga M and Spandidos DA: Deregulation of the tumor suppressor genes p14(ARF), p15(INK4b), p16(INK4ab) and p53 in basal cell carcinoma. Br J Dermatol 160: $1215-1221,2009$.

23. Li XS, Rishi AK, Shao ZM, Dawson MI, Jong L, Shroot B, Reichert U, Ordonez J and Fontana JA: Post-transcriptional regulation of $\mathrm{p} 21 \mathrm{WAF} 1 / \mathrm{CIP} 1$ expression in human breast carcinoma cells. Cancer Res 56: 5055-5062, 1996.

24. Rey MJ, Fernandez PL, Jares P, Munoz M, Nadal A, Peirò N, Nayach I, Mallofré C, Muntané J, Campo E, Estapé J and Cardesa A: p21WAF1/Cip1 is associated with cyclin D1CCND1 expression and tubular differentiation but is independent of p53 overexpression in human breast carcinoma. J Pathol 184: 265-271, 1998.
25. Berg T, Fliegauf M, Burger J, Staege MS, Liu S, Martinez N, Heidenreich O, Burdach S, Haferlach T, Werner MH and Lubbert M: Transcriptional upregulation of $\mathrm{p} 21 / \mathrm{WAF} / \mathrm{cip} 1$ in myeloid leukemic blasts expressing AML1-ETO. Haematologica 93: 1728-1733, 2008

26. Liang QC, Xiong H, Zhao ZW, Jia D, Li WX, Qin HZ, Deng JP Gao L, Zhang $\mathrm{H}$ and Gao GD: Inhibition of transcription factor STAT5b suppresses proliferation, induces G1 cell cycle arrest and reduces tumor cell invasion in human glioblastoma multiforme cells. Cancer Lett 273: 164-171, 2009.

27. Kanellou P, Zaravinos A, Zioga M, Stratigos A, Baritaki S, Soufla G, Zoras O and Spandidos DA: Genomic instability, mutations and expression analysis of the tumor suppressor genes p14(ARF), p15(INK4b), p16(INK4a) and p53 in actinic keratosis. Cancer Lett 264: 145-161, 2008. 